\title{
Thematic Review of Sukuk Ijarah Issued in Nigeria: An Opportunity for Economic Development
}

\author{
Ibraheem Alani AbdulKareem', Mohd. Sadad bin Mahmud', AbdulFattah \\ AbdulGaniyy2 \\ ${ }^{1}$ Faculty of Business and Management, Universiti Sultan Zainal Abidin (UNISZA) \\ Terengganu, Malaysia \\ E-mail: ibraheemalani1@yahoo.com \\ ${ }^{2}$ Department of Accountancy, Federal Polytechnic, Kaura Namoda, Zamfara State, Nigeria
}

\begin{abstract}
,
Ijarah Sukuk is becoming one of the most improved products in Islamic finance. It has become an alternative source of financing and liquidity for both private and public sectors. Also, it plays important role in development of the economy of Muslim and no-Muslim countries. The objective of this paper is to clarify the concept of Sukuk Ijarah and discuss its opportunity for economic development of the country. Also, the issues and challenges related to the implementation of Islamic finance particularly Sukuk by the Federal government of Nigeria (FGN) and also as an alternative to conventional bond. The paper adopts content analysis of relevant previous studies. Findings reveal the potential of Sukuk ijarah as an alternative for rapid economic growth and its functional role in attracting government and client to invest in it. Furthermore, the authors observe that misunderstanding among religious leaders is a major challenge to the growth of Islamic banks and implementation of Sukuk in Nigeria. It is recommended that workshops, seminars and conferences are to be organized by Islamic centres, financial institutions and academicians in Universities to spread knowledge and create awareness among Nigerians Muslims and non-Muslims about benefit and advantage of Islamic finance products and Sukuk in particular.
\end{abstract}

Keywords: Sukuk, Ijarah, Islamic finance, Liquidity

\section{INTRODUCTION}

Sukuk market has grown rapidly over the last few years in terms of numbers, size and sophistication. It is fast replacing conventional bonds and its being utilized in financing projects. It provides corporation and government with access to liquidity pool in addition to the traditional investor base (Ayu, Sary, \& Nanggolan, 2020; Godlewski, Turk-ariss, \& Weill, 2010). Sukuk market carries numerous benefits to the investors and issuers. Issuers can benefit from the massive increase in liquidity in the Islamic globe. An expanded number of multinational special purpose vehicle (SPV) are issuing sukuk to finance projects development. Moreover, government and corporate sectors have considered sukuk as an attractive source of financing (Ab Majid, Shahimi, \& Syah, 2011). Accordingly, Nafiu, Echchabi, and Alfarisi (2012) there are two factors that have added to the development of the shariah products. Namely, the improving trend of religiosity of Islam and the breakdown of the present capitalist financial system to benefit the society at large.

Furthermore, (Mohd Zin et al., 2011) emphasize that sukuk now has turned into the strongest sector in Islamic finance, that engaged in the international market and generate an important cross-border flow of funds as might be achieved beyond domestic markets. The investment in sukuk requires a fixed investment return with 
less risk and Shariah compliance. Sukuk can also be issued for new industrial projects. If sukuk is issued for businesses, it must certify that the holders have complete ownership in real assets(Ahmed, 2014).

Sherif and Hussnain, (2017) also underline that the most considerable development of asset in Islamic finance is sukuk. It has a structure comparable to conventional bonds but allow firm issuers to expand investments that abide by shariah principle. Similarly, Godlewski, Turk-Ariss, and Weill (2013) state that sukuk are investment certificates needed to finance new projects where profit and loss are shared between the holder and the issuer of sukuk, rather than conventional charging of interest rate. Sukuk as an Islamic form of bonds depend on profit and loss sharing. It is demonstrated that sukuk issuers have better performance than their conventional bond counterpart (Klein, Weill, \& Godlewski, 2018).

Many developed countries such as Japan, United Kingdom (UK), Singapore, Luxembourg and emerging economies such as Gulf Cooperation Council (GCC) and Malaysia have issued sukuk for their infrastructural development (Godlewski et al., 2013; Gelbard, Hussain, Maino, Mu, \& Yehoue, 2014; Hussain, Shahmoradi, \& Turk, 2015). Global sukuk issuance amounted to $\$ 116.7$ billion in 2017. The Figure below shows that global sukuk has increased from $\$ 87.9$ billion in 2016 to $\$ 116.7$ in 2017 and increase jump to around $32 \%$ volume (Labuan IBFC Inc., 2018).

Figure 1. Total Global Bonds Sukuk Insurance 2001-2017

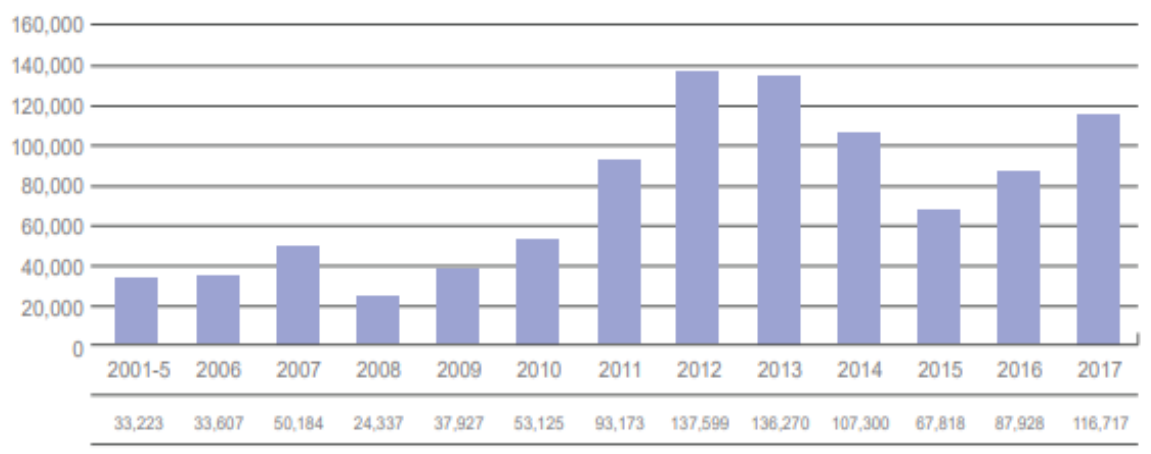

Source: (Labuan IBFC Inc., 2018).

Another reason behind the increasing popularity of sukuk is that it is deeply rooted in Islamic capital market. The most potential in sukuk issuance can achieve positive pricing in sukuk market when compared to conventional bond counterpart market (Zolfaghari, 2017). Sukuk are a kind of security which represent the claim of a bundle of assets or an asset (Adam \& Thomas, 2005). Occasionally people perceive that sukuk is like bonds. However, there are few differences between sukuk and bond, such as: nature of claims, security, purpose, principal and return, trading of security and duty of sukuk holders (Adam \& Thomas, 2005). The other distinctive nature of sukuk is the endorsement of shariah scholar to guarantee all aspect of sukuk issuance must fulfil the shariah standards. Also, Saeed, (1995) claim that the interest is a typical feature element in conventional bond and if the borrower fails to repay according to the schedule, the interest is increased and added to the principal amount. However, in Islamic finance no interest is charged even if the borrower is unable to repay by the 
time frame, neither can the amount financed by the lender be increased in event of default in payment or late payment. So also, the penalty cannot be enforced expect the borrower intentionally refuses to pay (Hussain et al., 2015a).

In spite of the success of sukuk and the opportunities it provides for governments and private sector, its application is not fully understood. There is little or no awareness on the economic benefits and infrastructural development sukuk provides in other countries. In Nigeria, its implementation is also being misconstrued as an attempt to Islamise the country (Ogunbado, Islam, Sharif, \& Ahmed, 2017; Sulaiman, 2020). COVID 19 is also changing the economic dynamics of the world and the epidemic may open more opportunities for Islamic finance products particularly sukuk markets by accelerating trends such as sustainability, social investment response which sukuk can handle (Parker 2020; Selim, Hassan \& Rahman, 2019). Against the backdrop of this virus, the sukuk will continue to play a critical role in economic growth and development of infrastructure in the coming year by accelerating access to financial services and transforming Islamic finance (AbdulKareem, AbdulGaniyy, Mahmud \& Yazid, 2020). Many studies emphasised that numerous Shariah-compliant instruments would be among of integrated pandemic response plans such as sukuk and zakat to enable nations to recover from economic problem during the COVID 19 epidemic (Brown, 2020; Osmanovica, Kb, \& Stojanovic, 2020; Rehman, 2020).

Therefore, the objective of this paper is to clarify the concept of ijarah sukuk in Nigeria and discuss its opportunity for economic development for the country. It also identifies issues and challenges facing Islamic finance in Nigeria especially sukuk as an alternative for road's rehabilitation and construction across six geopolitical zones in the country. The remaining part of this paper is structured as follows: section two explains the application of ijarah sukuk and the importance of Sukuk as an alternative to a conventional bond. Section three is on methodology. Section four discusses the FGN sukuk structure and explains the issues and challenges in the implementation of Islamic finance particularly sukuk in Nigeria. Section five highlights recommendations and concludes the discussion.

\section{LITERATURE REVIEW}

Sukuk are derived from the Arabic word of sakk for the singular and plural is sukuk. The term is utilized to represent legitimate instrument, deed and check. In practice, sukuk is utilized as papers indicating financial commitments from trade and business activities. In any case, sukuk as connected in the capital markets relates to the process of securitization and is commonly characterized as an Islamic bond (Kamil, 2008). The concept of Sukuk has been viewed differently by scholars and Islamic authorities. Sukuk are securities that comply with shariah principle and its investment principles, which prohibits charging or paying of interest (Liquidity Management Centre website., 2008). The Accounting and Auditing Organization for Islamic Financial Institution (AAOIFI) states that Sukuk must be tradable and be possessed by sukuk holders, with all obligations and right of ownership. The ownership include 
intangible asset, whether service or usufruct, the ability to be owned and sold legitimately in accordance with guidelines of shariah.

AAOIFI (2018) defines sukuk as "certificates of equal value representing undivided shares in ownership of tangible assets, usufruct and services or of the assets of a particular project or specific investment activity; however, this is true after receipt of the value of the sukuk, the closing of subscription and the employment of funds received for the purpose for which the sukuk were issued" (AAOIFI, $2018 \mathrm{p}$. 468). Under the AAOIFI investment, sukuk definition are said to represent undivided shares in ownership of tangible assets, services, usufruct, assets of specific projects or unique investment activity. Notice that AAOIFI definition does not include debt receivables or financial assets as possible asset classes that can be represented by the sukuk. Also, Islamic Financial Service Board (IFSB) (2018), defined sukuk as "Certificates that represent a proportional undivided ownership right in tangible assets, or a pool of tangible assets and other types of assets. These assets could be in a specific project or specific investment activity that is Shariah-compliant" (IFSB, 2018, p. 1).

In addition, the Securities Commission Malaysia (SCM) defines "sukuk as a financial document or certificate which represents the value of an asset evidencing an undivided pro rata ownership of an underlying asset" (Ahmad \& Abd Rahim, 2013, p.87). Islamic securities are securities issued pursuant to any Shariah principles and concepts approved by the SC's Shariah Advisory Council (SAC) (Mohamad \& Mohd Saad, 2012).Sukuk are often referred to as Islamic bonds. However, the right interpretation of the Arabic word Sukuk is Islamic investment certificates. In fact, various sukuk introduced in the market have been categorized as Islamic bonds rather than sukuk (Ahmad \& Abd Rahim, 2013). Cizakza (2010) argued that sukuk are certificates of equal value put to utilize as common right and share in tangle assets, services and usufructs or as investment activity or equity in a venture.

\section{Application of Ijarah Sukuk}

An Ijarah is a contract under Islamic principles and it is allowed by Islamic jurists. It is an agreement between two parties: the first is the lessor or financial institution and the second is the lessee. In Arabic terms, mujir is called lessor, the mustajir is called lessee and the ijarah is called rent. The ijarah is like an operating renting contract. The ijarah is among Islamic financing contracts which Islamic banks apply. In ijarah, the Islamic bank purchases an asset and rents it to the customer at an agreed price plus profit for a specific period at a fixed rental charge (Rahman, Hilmy, \& Saifurrahman, 2018). The term ijarah is used for leasing of property in accordance with an agreement under which an indicated permissible benefit in the form of usufruct is obtained for a predefined period in return for a predefined permissible consideration (AAOIFI, 2015). In ijarah, ownership of the rented asset remains in the hands of the lessor. The contract of ijarah is gaining popularity in the industry because the structure is productive and compliant with Shariah principle (Ahmad \& Abd Rahim, 2013). Uddin, Sultan, Hosen, \& Ullah, (2015) states that ijarah sukuk is the most recent product in the market that is quickly making progress in the capital 
market. Ijarah sukuk has emerged as a different classical asset among the Islamic finance products. It has gained acceptance among shariah scholars with high demand by huge investors and Islamic financial institutions (IFIs). On the supply side, not only sovereign but also corporate entities are likewise finding it valuable to generate funds for their project specific needs, working capital management, especially capital requirements and restructuring financing (Uddin et al., 2015).

The sukuk Ijarah is structure with the concept of rental with the right of lease to purchase the underlying asset rented on the final date of rental. The sukuk issued with agreement among sukuk holders and sukuk issuer to purchase the rental asset at maturity date. Though, the application of this sukuk involve sale and purchase at the inception stage (Hussin, Muhammad, \& Awang, 2012). As indicated by Shariff and Rahman, (2003) ijarah is a rent of a service or object including the transfer of usufruct for a lease consideration. This standard requires shariah compliant leasable and tangible asset, such as mechanism and property. In project financing, Sukuk ijarah is among the most commonly used principles because of its mechanism that is deployable for project financing structure. In Islamic jurisprudence the terms of ijarah is used for two main conditions.

The first ijarah type has to do with services given by people. Ijarah means to engage the service of a person, a compensation is paid to him/her for his/her employment and for agreed consideration between the lessee and lessor. There are examples of this in the Holy Quran, Allah has mentioned the word ijarah when Allah tells the story of prophet Shuaib and Prophet Moses in Sural Al- Qasas: "O my father, hire him. Indeed, the best one you can hire is strong and trustworthy" (Sural Al-Qasas verse 26-27). The prophet Muhammed (may Allah be upon him) also states that: pay the lessee or worker (Mustajir) his wages before his/her sweat is dried (Sahih AlBukhari, 2270). Furthermore, the Prophet Mohammed said that there are three people I will be an enemy of them in the Day of Judgement. One of these three is: "The man who employs a worker and do his work for him but does not pay him his wages" (Sahih Al-Bukhari, 2270). The second kind of ijarah has to do with asset. Here, ijarah is selling the benefit to exchange the usufruct of a specific property to someone in exchange for a wage or fixed price from the lessee. In this type of $\ddot{i j a r a h}$, the standard of the contract is similar to the principles of sales because two contracts include the transfer of properties to another (Ayub, 2007).

Sukuk ijarah constitutes the financial plan for durable asset that is related to an ijarah contract. They constitute the structure of rented assets and do not set up a relationship among sukuk holders and any organization. They are easily tradable at par, premium, or markdown in both secondary and primary market as determined by market. Sukuk ijarah involve three parties, namely the originator, sukuk holder and SPV. It is important for the terms of the agreement to be clearly defined in an ijarah contract (Jobst, 2009; Vishwanath, \& Azmi, 2009). The following six stages are the structure of sukuk ijarah.

1. The owners of the asset will be identified the projects or asset to be underlying asset.

2. The owners of the asset will sell the underlying asset to the SPV to raise fund. 
3. SPV issued sukuk and collect fund from investors and given sukuk certificate to the investors.

4. SPV will enter into rental agreement with the issuer.

5. The rental amounts gotten by SPV from the issuer which will distributed to the investors.

6. At time of maturity the SPV will sell the underlying asset of Ijarah to issuer with agreed price to redemption sukuk certificate (Rafay, Sadiq, \& Ajmal, 2017; Sulaiman. A.K, 2012)

Furthermore, Mohd Zin et al., (2011) posits that, sukuk ijarah is divided into a lease agreement, purchase undertaking, services agreement and purchase agreement. It is considering letting property rights to other to benefit according to the agreed price. Sukuk ijarah is issued on a leaseback and sale arrangement of real estate and has been a well-knowing structure for sovereign issuer. The SPV applies to buy land from the originator and rents it back to the originator. The originator agrees to repurchase the asset at maturity or upon schedule settlement of the original purchase price. The SPV is required by shariah principle to undertake the major maintenance of the property but will frequently appoint the obligor to carry out such activity for its benefit (Yahya, Hussin, \& Muhammad, 2012).

As indicated by Saeed and Salah (2012), the structure of sukuk ijarah depends on the contract of ijarah. An ijarah contract permits the transfer of the usufruct of an underlying asset to the lessee in return for the rental payment, which is like the traditional lease contract. In this way, the sukuk depend on the basic underlying asset that the SPV has obtained rather than securities debt which is the case in traditional bonds. Hence, the structure of sukuk ijarah uses the leasing contract as the base for the return paid to sukuk holder, who are the owner of the underlying asset and all benefit from the rentals as well as sharing risk.

Al-Bashir (2012) identify three differences between conventional and Islamic lease concept. First, Islamic lease must be free from any kind of interest or any arrangement that may contain any component of interest payment. Second, the nature of the rented asset should be in line with the Islamic point of view and that asset should be allowed and might be utilized for acceptable functions. Third, ijarah draws clear differences between the responsibilities and role of the lessor (owner of the property) and the lessee (hirer) where every major maintenance and capital cost are the responsibility of the lessor as the property owner, while daily maintenance cost would be the duty of the renter as beneficial of the usufruct (Rafay et al., 2017).

\section{Difference Between Asset Backed and Asset Based In Sukuk Structure}

According to SCM, (2009) sukuk are categorized into asset backed and asset based sukuk structure. Hidayat (2013) noted that in asset backed sukuk, there is a real sale and absolute transfer of asset to the third part which is SPV. The SPV acts as a trustee on behalf of sukuk holder and manage the asset profit that is remitted from investment and transfer it to the sukuk holder. The SPV collects money as the issuer of the sukuk and manage the assets, whereas, the ownership of the asset will belong to 
the sukuk holder. Since underlying asset has been separated from the book of originator, there would not be recourse to the obligor. It should be noted that, for asset backed sukuk to be acceptable from shariah perspective, it must be free from any dispute or legal issues, must not have obstacle that void the real transfer of the asset from the obligor to the SPV who act as a trustee on behalf of sukuk holder and must generate cash flow from the underlying asset (Hidayat, 2013). In contrast, Sukuk holder does not have the right of ownership of the asset under the asset based sukuk. If there is a deficit in the payment, the sukuk holders have recourse to the obligor not underlying asset. Because they are beneficial ownership not legal owner of the asset. Beneficial ownership has rights of the property that belong to a person despite the legitimate title of the assets belongs to someone else. Sukuk holders owned the asset under the asset backed sukuk and do not have recourse to the obligor if there is a deficit in payment (Tahmoures, 2013).

Therefore, there are many sukuk involving sale of the underlying assets from the originator to SPV but in many sukuk the originator just transfer beneficial ownership of the asset to the SPV not legal title (Thani, 2012). According to Ellias, Haron \& Mohammed (2013) a major criticism from shariah scholars on sukuk are the issue of beneficial ownership in relation to asset based sukuk. Since sukuk represents sukuk holder ownership over certain asset, some practitioners and scholars of Islam discussed whether ownership of sukuk holder concurred with requirement of shariah. In many countries including Malaysia, sukuk issued is asset based structure and not asset backed because of the limitation on foreign ownership of certain assets. Hence, in such situation, the sukuk holders is only guaranteed security interest in the sukuk asset and sukuk holder are recognised as creditors and not owners of the asset. Also, if there is foreclosure or asset disposal, surplus must be returned to the obligor. (Aziz, Shahid, \& Ibrahim, 2013; Bahari, Ahmad, Shahar, \& Othman, 2016).

Usually, the ownership for rented asset remains in the hands of the lessor. According to the structure, the sukuk holders possess equal shares on the underlying asset or its usufruct. Essentially, the sukuk holders possess the right to the asset and collect the rental payment (Yaakub, Shah, Mujani, Jusoff, \& Hamid, 2011). Once more, these rights rely upon the structure of ijarah whether asset based ijarah sukuk or asset backed ijarah sukuk. Asset backed ijarah sukuk permits the holders of sukuk to liquidate the underlying asset in any case of default to recover most of their investments while asset based ijarah sukuk only represent beneficial ownership on the underlying asset and it limits sukuk holders right in the event of default (Yaakub et al, 2011).

\section{Sukuk and Conventional bond}

Sukuk are Islamic financial certificates that are frequently mentioned as Shariah complaint bonds. Both bonds and sukuk are sold to the investors who then get a stream of payments till a set date of maturity. Sukuk are compliant to the Shariah which anybody cannot generate money from money which is tantamount to the riba. This is based on the principle that it is improper for any commodity, including money to increase in value simply by lending money to another person. However, Islamic law 
does not disallow investors from making a profit/return on the capital if the capital provider is willing to share the risk with entrepreneur. The conventional bonds are always interest (riba) based since the payment is fixed (Alam, Hassan, \& Haque, 2013; Bhuiyan, Puspa, Saiti, \& Ghani, 2020). Furthermore, bonds are different significantly from sukuk in a way that the return of bonds to bondholders indicate the right to claim indebtedness for the money borrowed. Whereas the return to the sukuk investors indicate the right to benefit payments from a trade transaction or the claim of ownership of the venture (Bhuiyan et al., 2020). While conventional bonds and Sukuk are very alike in nature but there are some important differences to be aware of:

1. Ownership of sukuk asset and debt obligation: sukuk backed by underlying tangible asset and sukuk holders given partial ownership in the underlying asset of sukuk with actual value while bonds ownership indicates merely a debt obligation.

2. Shariah complaint and not comply with Shariah: the underlying asset of sukuk must be complaint with Shariah. This means that any investment prohibited from shariah cannot be financed such as sale of alcohol, gambling, pork products, tobacco, pornography and so on. It also prohibits financial institutions from been involved in any interest based transactions. On the other side, underlying asset of bonds may not comply with principle of shariah it can be utilized to finance any business, projects, assets or join investment that complies with western legislation.

3. Sukuk asset value and bonds asset credit worthiness: value of sukuk is based of market value of the underlying asset of sukuk which can increase in value when the asset of sukuk increases in value while bonds is based on credit worthiness on the neck of the issuers

Selling underlying asset of sukuk and selling of bonds: when sukuk investors sell asset of sukuk they sell ownership of asset that backs the sukuk. In terms of bonds, the investors sell debt which is the relationship between bond holders and bond issuer (AbdulKareem, I.A, Mahmud, M.S, AbdulGaniyy, A.F, \& Yazid, 2020)

\section{METHODS}

The paper uses descriptive approach of qualitative method. This depends on secondary data that has been gathered and is available in electronic form; published or unpublished materials (Curtis, 2008). Johnston (2017) identify further secondary data as data that was collected by another person for another primary purpose. The usage of this current data provides a viable alternative for researchers who may have limited time. Secondary data is an experimental exercise that applies the same basic research principles as studies using primary data and has steps to be followed just as any research method (Doolan, \& Froelicher, 2009)

\section{DISCUSSION}

\section{Overview of Sukuk in Nigeria and its Structure}

According to theUnited Nations Population Division (UNPD's) world population prospects, Nigeria's as population stood at 185.9 million in 2016 with $2.6 \%$ 
growth rate when compared with 2015 estimation. Nigeria is the most populous country in Africa, representing approximately $47 \%$ of the entire population of West Africa. Nigeria has a relatively young population, with $2.7 \%$ of the population aged 65 above, between ages of 15 and 64 is $53.3 \%$ and under 15 is $44 \%$, as of the end of December 2015 (Nganga, 2016; Ogunbado et al., 2017).

In January 2012, the CBN granted Jaiz bank an endorsement to operate as a regional interest free bank in Northern part of Nigeria with three branches situated in Abuja, Kano and Kaduna. Thus, Jaiz bank became the first and the full-fledged bank to operate Islamic banking in Nigeria. It started with three branches in 2012 but now its branches has increased to 17 . Also, there are other banks operating Islamic banking windows in Nigeria. Islamic banking advocates the principles of profit and loss sharing among investors (Bello, 2016; Rita, 2013; Yahaya, \& Lamidi, 2015). Oladunjoye (2014) explains the possibility of using Islamic finance, especially sukuk as a mechanism for raising capital and development of infrastructures in Nigeria. In 2013 the first sukuk was issued by Osun state government of Nigeria and which is the first of its kind in sub-Sahara Africa (SSA). The N6o Billion Debt Issuance was meant to fund the development of 20 High Schools, two middle level schools and two elementary schools in Osun State, Nigeria. This sukuk issued at a rate of $14.75 \%$ per annum at N1,0oo per unit and would mature on o8 October 2020. This first sukuk issued by Osun state government would bring the huge possibilities for Islamic finance in the country (Oji, 2015; Sulaiman, 2020).

Similarly, in 2016 the Federal Government of Nigeria (FGN) followed suit by issuing 100 billion naira of sukuk ijarah for 25 road infrastructure projects throughout the federation. The sukuk, which has been illustrated as a low risk and save investment, was issued by the Debt Management Office (DMO) with seven years tenor (Jannah, 2017; Odunsi, 2017). In addition, the sukuk attracted an oversubscription of 105.9 billion naira, indicating investors' desire and demand for sukuk. The proceed from FGN sukuk issuance is expected to be utilized to finance infrastructure development in the country especially, the rehabilitation and construction of road infrastructure.

Onihaa (2017) expresses that this first sukuk issued by FGN has raised a lot of enthusiasm as well as questions from the public. Thus, there is the need to enlighten public more about sukuk issuance in the country. Sukuk is one of the financial instruments utilized by organizations and governments to raise funds. Furthermore, unlike traditional bonds whose fund can be utilized for various purposes including recurrent expenditure, funds achieved from sukuk issuance can only be utilized for assets such as infrastructure. Moreover, investors receive income, according to the assets rather than interest, as in the case with traditional bonds.

Onihaa (2017) further stated that why FGN issued sukuk as alternative for conventional bond. Before this time, FGN had borrowed money from the domestic market through the traditional bonds such as FGN bonds, Nigeria Treasury Bills (NTB), and FGN saving bond. Issuance of sukuk as a new instrument by FGN currently around is another landmark in the domestic market that has huge benefit and advantage to the government, investors, capital market and Nigeria masses for 
different reason. Among the three strategic objectives of the Economic Recovery and Growth Plan (2017-2020) is to set up worldwide competitive economy. One of the strategies for obtaining this is by investing in infrastructure. Therefore, every avenue towards growing Nigeria infrastructure must be tapped. The utilization of the Sukuk to raise funds to finance infrastructure contributes directly to achieving this target. Also, Vanguard (2017) postulate that Nigeria economy needs good roads for development; because they link different parts of the nation, facilitate trade, provide access to markets for farmers and connect remote areas to vital social service such as health and education. In addition, sukuk issuance will also motivate financial inclusion by providing an opportunity for non-interest investors to participate in the fixed income market. Furthermore, it gives a chance to develop the saving culture in Nigeria, especially among individual and other retail investors. To motivate the investment culture and mobilize savings, the rental sukuk income is tax exempt (IMF and Word Bank, 2017; Vanguard, 2017). Figure 1.1 below indicates Structure of Sukuk Ijarah issued by FGN.

Figure 1.1: Structure of Sukuk Ijarah issued by FGN

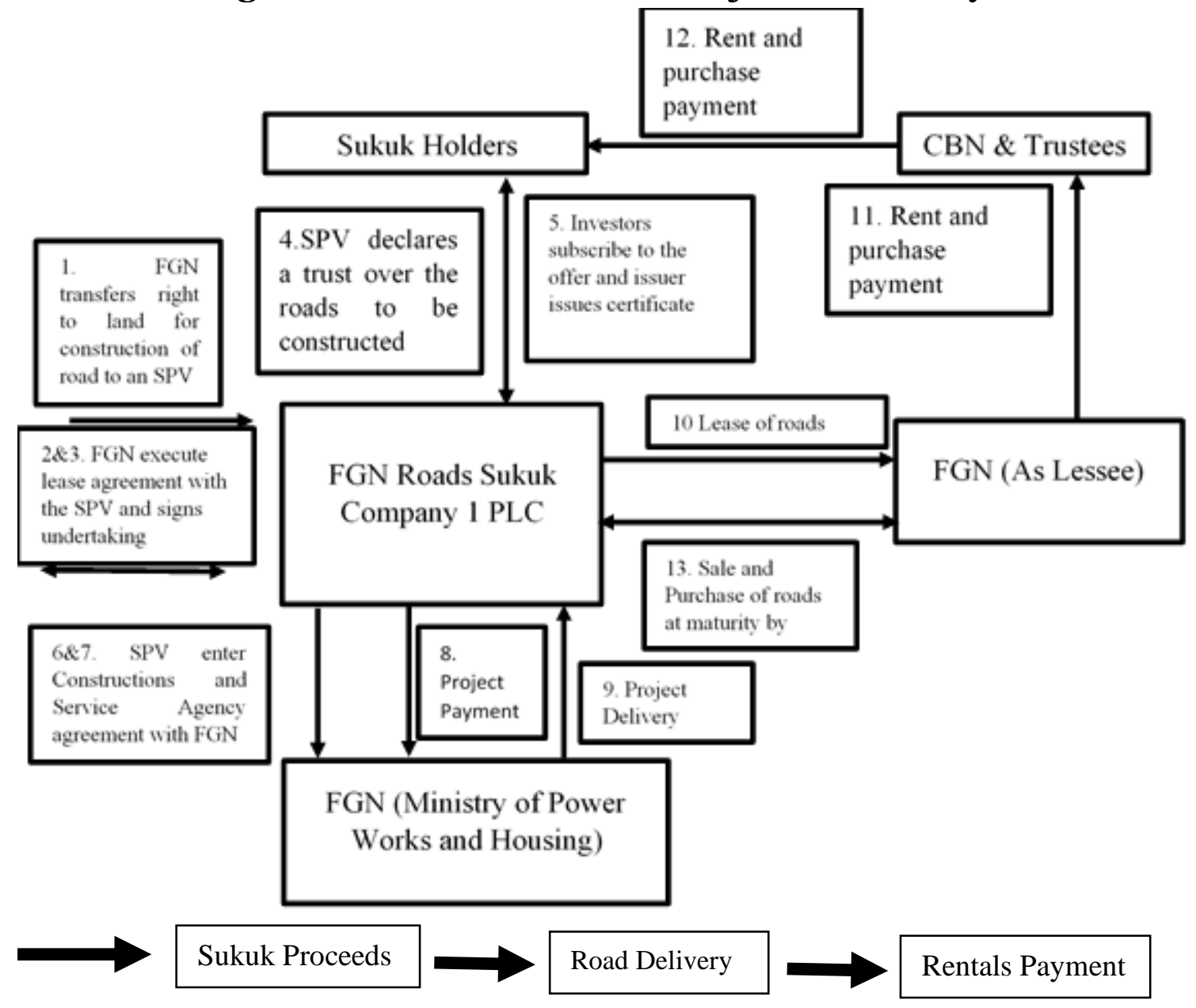

Source: (FGN, 2017). 
An overview of Sukuk Ijarah Structure

1. FGN issues a letter of distribution of certain land to the trustee/issuer for rehabilitation and construction of highways.

2. FGN through the Federal Ministry of Power, Works and Housing (FMPWH) implements an Ijarah agreement with the trustee /issuer to lease constructed roads.

3. Purchase undertaking is implemented by the FGN to purchase constructed roads from the Trustee/Issuer at maturity.

4. Trustee/Issuer declares as a trust over the roads to be constructed for the Sukuk holders under the declaration of trust deed and nominates STL trustees limited and FBN trustees limited to carry out its functions as trustee under the trust.

5. Sukuk holders subscribe to the offer and the Trustee/Issuer issues electronic investment certificates through the CBN as registrar.

6. Trustee/Issuer enters into a construction agency agreement (CAA) with FMPWH to choose contractors to supervise/construct the road.

7. Trustee/Issuer also enters into a service agency agreement (SAA) with the FMPWH to undertake major repairs on the road after construction.

8. Trustee/Issuer pays the workers through the FMPWH for rehabilitation and construction of roads from the Sukuk proceeds after the work done by the contractors are certified by delegate trustees and FMPWH.

9. After completed roads the contractors deliver to the Trustee/Issuer through the FMPWH.

10. Trustee as a lessor will leases the roads to the FGN in accordance with the Ijarah contract.

11. FGN pays periodic rentals for the utilization of the roads.

12. CBN would transfers the periodic distribution amounts to Sukuk holders.

13. At maturity date FGN would purchase the road back.

Table 1. Main Terms of The Sukuk

\begin{tabular}{ll} 
Issuer & FGN Roads Sukuk Company 1 Plc. On behalf of the FGN \\
Description & FGN Sovereign Sukuk due 2024 at a return of 16.4796 \\
Tenor & 7 Years \\
Issue Size & N100.000.000.000 \\
Unit of Issue & N1.00 per unit \\
Minimum Subscription & Minimum of N10.00o (i.e 10 units @ N1.00o/unit) and in \\
& multiples of N1.00o (1unit) thereafter \\
Rental payment & Semi-annually \\
Redemption & Bullet payment of investment funds at maturity \\
Paying Agent/Register & Central Bank of Nigeria \\
Security & Backed by the full faith and credit of the FGN \\
\hline
\end{tabular}




\section{Legal Framework Guiding the Principles of Islamic Banking in Nigeria.}

Having established the principle of Islamic banking in Nigeria and presented how it came into existence, the legal framework that guides its day-to-day operations shall be discussed in this segment. The beauty of a legal framework is its permissibility for private and government businesses, not minding whether it is local or international to prosper or allows its growth. Nigeria is a common law country, which has no devoted laws for Islamic banking and finance. Conversely, the legal system for Islamic banking and finance is derived from current traditional finance laws by utilizing on certain arrangements to establish Islamic banking and finance institutions. Provisions in banks and others financial institutions Act 1991 (BOFIA) and CBN Act 2007 enable the Governor of $\mathrm{CBN}$ to make rules and regulations to issue guidelines for the operation and control of all institutions under the supervision of CBN. Also, the provisions enable CBN to supervise and regulate the activities of specialized banks including profit and loss sharing banks (IFSB, 2018).

In addition, there is no certain law for sukuk activity in Nigeria, but the provision of the investment and securities Act 2007 enable the securities and exchange commission (SEC) to register and control securities exchanges, corporate and individual capital market operations and collective investment schemes (IFSB, 2018). Also, Abdullahi (2016) posits that the Act permits the SEC to establish specialized department for regulating and developing Nigeria capital market and to make rules and regulations that would guarantee the smooth working of the capital market. Under these arrangements, the establishment of Islamic fund and listing of the sukuk by the SEC becomes conceivable (Nmadu \& Mika'ilu, 2018).

Mohammed (2015) furthermore mention that, the CBN has issued rules on Shariah governance for non-Interest financial institutions (NIFI) in the country with four major areas: (i) setting out guidelines and procedures in establishment of Shariah Advisory Committee (SAC) of NIFI; (ii) describing the role and responsibilities of the committee and its members; (iii) outlining the function relating to Shariah review and audit processes and (iv) describing the relationship and working arrangement between CBN Shariah council and committee. Rules on Shariah governance issued by CBN in 2010 clearly state that all licensed IFIs should establish a SAC that must be approval by the regulators (COMCEC, 2017; IFSB, 2018).

\section{Issues and Challenges in Implementation of Islamic Finance in Nigeria}

There are many issues and challenges following the establishment of Islamic banking and finance in Nigeria. Nigeria as a multi-religious country, the adoption of Islamic banking and finance is alleged as a way to Islamize the country (Ogunbado et al., 2017). Also, there has been a campaign against implementation of sukuk ijarah structure by the FGN. The campaign was organized and planned by Christian Association of Nigeria (CAN). This emotional outburst started since the first license to implement non-interest banking system was granted by CBN. Again, the implementation of sukuk was tainted with religious emotion. According to Godwin (2017) many countries around the world have issued sukuk in the past but the case of 
Nigeria is different. Religious authorities in Nigeria are always intolerant over any religious matters (Yunusa \& Nordin, 2015).

Many Christians view that granting Islamic banking and finance to operate in Nigeria would permit the Islamization of the country. They feel that Islamic and Muslims activities could control the economic activities while Christianity would most likely be deserted (Chidi, Clementina, \& Onyike, 2013). This can be perceived from the report issued by a prominent CAN member, Archbishop of God-Do-well Awomakpa where he said:

"It has become increasingly obvious that the Islamic community has stepped up its determination to totally Islamize Nigeria as a nation. The observation is clear from the ongoing efforts to establish Islamic banking in Nigeria through the instrumentality of the Central Bank Governor, Malam Lamido Sanusi" (Quoted in Adegboyega, 2013, p.22).

Also, another prominent CAN member, Anthony Cardinal Olubumi Okogie observed that it is to supress Nigerian Christianity. He said: "We are against the operation of Islamic Banking in Nigeria because we see it as another deliberate move to subjugate Christianity in Nigeria" (Adegboyega, 2013 p. 22).

In another event, it is revealed that the leader of the CAN Pastor Ayo Oristejapor and their General secretary Rev. Musa Asake blamed the CBN Governor for being sectional and bringing religion into Nigeria's financial system by introducing Islamic banking. They stated that CAN will never support the system because doing that would mean encouraging discrimination and disunity in the nation. They further contend that why Islamic bank and finance be given a different rule?. The CBN ought to rather give one single rule that could cater for every Islamic banking and finance industry as well as the Christian non-interest banking (Sulaiman, 2020; Yunusa \& Nordin, 2015). Each law that has been declared to back the Sukuk issuance and promote an Islamic banking and finance system in Nigeria is ultra vires, void, illegal and null.

Rev. Asake said"

"The FG must dismantle all legal and institutional framework established to promote Islamic financing in Nigeria. We affirm that the territorial integrity of Nigeria is undermined through the issuance of Sukuk in the country. We hope that the government shall desist from its policies of unbridled religious sectionalism" (Godwin. A.C, 2017; Ogunbado et al., 2017).

Opejobi, (2017) in response to the CAN stated that one of prominent of human right lawyer in country confronted CAN to Christianise Nigeria by establishing interest free banks in the country. He further clarified that sukuk is an authentic method to develop infrastructure from which government would generate funds and sukuk are normal practice everywhere in the world. Also, FGN denied any arrangement to Islamize the country. The government stated that the financial initiative was as a result of the need to contain people who were against interest yielding businesses. While sukuk is not an effort to Islamize the country in any structure. Rather, it is an effort at financial inclusiveness. Difference between conventional bond and sukuk is that interest earning is prohibited under sukuk transaction. Along these lines, this would benefit those who believe that money cannot earn money without taking risk (Godwin. 
A.C, 2017). Also, Nigeria Supreme Council for Islamic Affairs (NSCIA) has claimed that CAN is showing itself to be Islamophobic. Despite the remarkable tolerance from Muslims over the years, CAN appears to be increasingly becoming Islamophobic and paranoid about its hate and intolerance of Islam, casting aspersions, unnecessarily overheating the polity and unjustifiably creating fear and distrust in the minds of peace loving citizens of our great country (A.Mallum, 2016; Godwin. A.C, 2017).

Besides, World Bank has been engaged in Islamic finance and certainly on sukuk issuance as well. Interestingly, many non-Muslim countries across Europe, Asia and Africa have introduced Islamic finance in their system particularly sukuk for infrastructure development (COMCEC, 2019; IFSB, 2014). Worthy of mention here are Tanzania, Kenya, China, Luxembourg, South Africa, Russia, Singapore, UK and various firms in the United Stated (US). In recent years, British government facilitated world conference on Islamic Banking and Finance and David Cameron, the then British prime minister openly announced that their expectation is to make UK centre for Islamic finance worldwide (IFSB, 2018). As regards Africa region, Islamic finance has made substantial development and its encouraged with demand by Muslims and non-Muslims. Countries such as Gambia and Sudan have entered in sukuk issuance in the past (Labuan IBFC Inc., 2018). Prior to Nigeria, South Africa also issued sovereign sukuk (Godwin, 2017). Also, South Africa attempts to make country the hub for Islamic finance in Africa. The country has amending tax law to create field for Islamic finance. Currently, the country has Al Baraka Bank as a full-fledged Islamic bank. The was registered in 1989 and other banks such as Absa Bank, First National Bank (FNB) and HBZ Bank house Islamic finance windows working alongside with their traditional banking services. In addition, South Africa Treasury issued first sukuk in end part of 2014 with amount USD500 million 5.75 year and which was oversubscribed more than four times and it attracted investors from Asian and Middle Eastern region (Desai, 2016; IMF and Word Bank, 2017).

Also, in West Africa region, Senegal successful implemented a four year XOF100 billion ( $\$ 171.96$ million) sukuk issuance in June 2014. This sukuk issuance represents a new year in the utilization of Islamic finance in the Senegal's public finances. The country may consider sukuk issued to boost Senegal's infrastructure needs and Dakar is aiming as the continent's centre for Islamic finance (Al Natoor, 2015; Desai, 2016; Hussain, Shahmoradi, \& Turk, 2015b; Labuan IBFC Inc., 2018). In addition, Cote d'Ivoire inaugurated its debuts 5 year tenue with amount of 150 billion CFA sukuk issuance at profit rate of 5.75\% in the end of 2015 (Desai, 2016). Also, in East Africa region, Uganda government has endorsed the Financial Institutions (Amendment) Bill in 2015, which pave way for Islamic finance to operate in the country. Kenya government also has set vision to becoming Islamic finance centre in the East Africa with two full-fledged of Shariah compliant banks in operation, licensed Takaful and re-Takaful and many financial institutions offering products that fulfil with Shariah (Desai, 2016; Labuan IBFC Inc., 2018). Thus, it can be observed that religious misinterpretation statement or unnecessary Islamophobia culture is an immense challenge facing development of Islamic banking and finance in Nigeria. 


\section{CONCLUSION}

The understanding and harmonization among different religious leaders in the country would enhance the growth of Islamic finance particularly sukuk which will make it easier to issue another sukuk for the infrastructural development. This would accelerate economic growth in Nigeria. Based on previous studies sukuk has gained significant performance globally. Outstanding issuance amounted to $\$ 116.7$ billion in 2017. FGN should not be ambiguous on guidelines and it must mention clearly policies and rules for conducting sukuk issuance. The practices and concepts of sukuk should be clarified and explained to clear away all sorts of misinformation and misconceptions about issuance of sukuk. Also, sukuk issuance around the globe indicated as alternative to conventional bond which is not affiliated with any religious or ethnic group. The authors observe that the solid religious affiliation of Nigerians which have made them to be so emotional on any matter that has symbol of religion and hard feelings among Islam and Christianity prevents them from looking at positive impacts of Islamic finance globally.

The unity, friendship and harmony should be embedded in every community that would give room to development and growth of the country. In addition, religious authorities must be called to order; hate speeches on social media must be banned. FGN is advised to create free relationship among religious leaders and enable intellectual sessions to share their opinions and views. In order to achieve this, workshops, seminars and conferences are to be organized by Islamic centre, financial institutions and academicians in Universities at state level to spread knowledge and create awareness among Nigerians Muslims and non-Muslims. This will enable tangible understanding of the meaning of Islamic banking and finance particularly sukuk in the country. This will also reduce misunderstanding and misinterpretation of Islamic finance in the country because people have limited awareness about Islamic finance products such as Ijarah, Mudarabah, Sukuk, Musharakah and so on. The level of awareness in Islamic products in Nigeria is less compared with other countries in Africa due to majority of people in Nigeria do mot know how Islamic finance operate.

\section{REFERENCES}

A.Mallum. (2016). The Operational Implication of the Challenges of Islamic Banking in Nigeria. Annals of Borno, XXVI(June), 153-166.

AAOIFI. (2015). Shariah Standards Accounting and Auditing Organization for Islamic Financial Institutions, Kingdom of Bahrain.

AAOIFI. (2018). Shari'ah Standard No. (17). Accounting and Auditing Organization for Islamic Financial Institutions.

Ab Majid, H., Shahimi, S., \& Syah, H. (2011). Sukuk Defaults and Its Implication: A Case Study of Malaysian Capital Market. 8th International Conference on Islamic Economics and Finance, Qatar, (September 2015), 19-21. Retrieved from https://www.researchgate.net/publication/265085046

AbdulKareem, I.A, AbdulGaniyy, A.F, Mahmud, M.S, \& Yazid, A.S . (2020). Alternative Way to Reducing Poverty and Inequality in Nigeria from Islamic Perspective. Journal of Islamic Banking and Finance, 37(2), 73-83. 
AbdulKareem, I.A, Mahmud, M.S, AbdulGaniyy, A.F, \& Yazid, A.S . (2020). Shariah Issues in the Application of Repurchase Undertaking in Sukuk Mudarabah. International Journal of Business and Technopreneurship, 1O(2), 173-182.

Abdullahi, N. A. (2016). Islamic Banking in Nigeria: Issues and Prospects. Journal of Emerging Economies and Islamic Research, 4(2), 34. https://doi.org/10.24191/jeeir.v4i2.9085

Adegboyega, A. J. (2013). Excogitative Deconstruction of the Discourse Dynamics of the Controverted Non-Interest Banking and the Islamicizing Controversy Issues. Journal of Islamic Economics , Banking and Finance, 9(1), 21-38. https://doi.org/10.12816/0001591

Ahmad, N., \& Abd Rahim, S. A. (2013). Sukuk Ijarah vs. Sukuk Musyarakah: Investigating Post-Crisis Stock Market Reactions. International Journal of Humanities and Management Sci-Ences (IJHMS), 1(1).

Ahmed, E. R. (2014). ISLAMIC SUKUK : PRICING MECHANISM AND RATING Md . Aminul Islam Tariq Tawfeeq Yousif Alabdullah Contribution / Originality 2 . CONCEPT OF SUKUK SECURITIES. Journal of Asian Scientific Research, 4(11), 640-648.

Al Natoor, B. (2015). Islamic finance in Africa in its infancy; important initiatives underway. Islamic Finance New. Retrieved from https://www.islamicfinancenews.com

Alam, N., Hassan, M. K., \& Haque, M. A. (2013). Are Islamic bonds different from conventional bonds? International evidence from capital market tests. Borsa Istanbul Review, 13(3), 22-29. https://doi.org/10.1016/j.bir.2013.10.006

Ayu, U., Sary, F., \& Nanggolan, Y. A. (2020). Underlying Assets and Sharia Governance Mechanism on Sukuk Yields.

Ayub, M. (2007). Understanding Islamic finance. (John Wiley \& Sons Ltd 2007) 380. Aziz, M. R. A., Shahid, M. F. I., \& Ibrahim, M. F. (2013). The Structure of Sukuk Ijarah: An Initial Analysis from The Perspective of Maqasid Al-Shariah. In In Paper Proceeding of the 5th Islamic Economics System Conference (iECONS 2013)," Sustainable (pp. 4-5).

Bahari, N. F., Ahmad, N. W., Shahar, W. S. S., \& Othman, N. (2016). A Review on the Potential Growth of Sukuk, Issues and Its Challenges. International Conference on Economics and Banking, 2016(2), 395-403. Retrieved from http://conference.kuis.edu.my/iceb2016/eproceedings/EBo40.pdf

Bello. O, A. (2016). Islamic Banking Products and Challenges in Nigeria. Retrieved from http://saharareporters.com/2016/12/25/islamic-banking-products-andchallenges-nigeria

Bhuiyan, R. A., Puspa, M., Saiti, B., \& Ghani, G. M. (2020). Comparative analysis between global sukuk and bond indices: value-at-risk approach. Journal of Islamic Accounting and Business Research, 11(6), 1245-1256. https://doi.org/10.1108/JIABR-02-2018-0019

Brown, S. (2020). How COVID-19 will reshape Islamic finance markets. 37 th the Jakarta post. Retrieved from https://www.thejakartapost.com/academia/2020/06/05/how-covid-19-will- 
reshape-islamic-finance-markets.html

Chidi, B., Clementina, E., \& Onyike, I. E. (2013). Press Coverage of Islamic Banking Controversy in Nigeria : A Job Not Well Done, 18(2005), 25-35.

Cizakza, M. (2010). Domestic borrowing without the rate of interest: Gharar and the Origins of Sukuk. Symposium on Sukuk Financial Instruments, (23205), 1-23. Retrieved from http://mpra.ub.uni-muenchen.de/23205

COMCEC. (2017). Diversification of Islamic Financial Instruments. Standing Committee for Economic and Commercial Cooperation of the Organization of Islamic Cooperation (COMCEC).

COMCEC. (2019). Infrastructure Financing through Islamic Finance in the Islamic Countries.

Curtis, K. R. (2008). Conducting Market Research Using Primary Data. Chapter 7 of Niche Markets: Assessment \& Strategy Development for Agriculture, 1-10.

Desai, M. I. E. (2016). Islamic Finance-Opportunities and Challenges. Journal of Islamic Banking and Finance, 33(1), 86-90.

Doolan, D. M., \& Froelicher, E. S. (2009). Using an existing data set to answer new research questions: A methodological review. Research and Theory for Nursing Practice. An International Journal, 23(3), 203-215.

Ellias, M. R. F., \& Haron, M.N \& Mohammed, M. F. (2013). Shariah issues in sukuk 1. Retrieved from http://www.maybank2u.com.my/iwov-resources/islamic my/document/my/en/islamic/scoe/knowledge-centre/research paper/Shariah_Issues_in_Sukuk.pdf.

FGN. (2017). FGN ROADS SUKUK COMPANY 1 PLC/Pursuant to the Local Loans (Registered Stock and Securities) Act, CAP. L17, LFN 2004. Abuja.

Gelbard, E., Hussain, M., Maino, R., Mu, Y., \& Yehoue, E. (2014). Islamic Finance in Sub-Saharan Africa: Status and Prospects. IMF Working Papers, 14(149), 1. https://doi.org/10.5089/9781498348669.001

Godlewski, C. J., Turk-ariss, R., \& Weill, L. (2010). Are Sukuk Really Special ? Evidence from the Malaysian Stock Exchange. University of Strasbourg, (APRIL 2010), 1-33.

Godlewski, C. J., Turk-Ariss, R., \& Weill, L. (2013). Sukuk vs. conventional bonds: A stock market perspective. Journal of Comparative Economics, 41(3), 745-761. https://doi.org/10.1016/j.jce.2013.02.006

Godwin. A.C. (2017). SUKUK bond: Federal government planning to Islamize Nigeria through back door -CAN insists. Retrieved from http://dailypost.ng/2017/o9/20/sukuk-bond-federal-government-planningislamize-nigeria-back-door-can-insists/

Hidayat, S. E. (2013). A Comparative Analysis between Asset Based and Asset Backed Sukuk: Which One is More Shariah Compliant? International SAMANM Journal of Finance and Accounting, 1(2), 24-31. https://doi.org/ISSN 23082356

Hussain, M., Shahmoradi, A., \& Turk, R. (2015a). An Overview of Islamic Finance. IMF Working Papers, 15(120), 1. https://doi.org/10.5089/9781513590745.001

Hussain, M., Shahmoradi, A., \& Turk, R. (2015b). An Overview of Islamic Finance. 
IMF Working Papers (Vol. 15). https://doi.org/10.5089/9781513590745.001

Hussin, M. Y. M., Muhammad, F., \& Awang, S. A. (2012). Development of sukuk ijarah in Malaysia. Journal of Islamic Economics, Banking and Finance, 8(2), 91102.

IFSB. (2014). Prospects and Challenges in the Development of Islamic Finance for Bangladesh.

IFSB. (2018). Islamic Financial Services Industry Stability Report. Retrieved from file://C:/Users/ibraheem/Downloads/Islamic Financial Services Industry Stability Report 2018_En.pdf

IMF and Word Bank. (2017). Sovereign Sukuk Roundtable.

Jannah. C. (2017). How FG will spend N10obn Sukuk bond - Fashola. Retrieved from http://dailypost.ng/2017/09/26/fg-will-spend-n1oobn-sukuk-bond-fashola/

Jobst, A. (2009). Islamic securitization after the subprime crisis. Journal of Structured Finance, 14(4), 41-57.

Johnston, M. P. (2017). Secondary data analysis: A method of which the time has come. Qualitative and Quantitative Methods in Libraries, 3(3), 619-626.

Kamal-deen Olawale Sulaiman (Ph.D). (2020). ( 46 )............................................................. CUSTOMER , S EXPECTATIONS IN SUKUK ( ISLAMIC BOND ) CUSTOMER 'S EXPECTATIONS IN SUKUK ( ISLAMIC BOND ) ( 45 ), (55), 23-45.

Kamil, W. A. R. (2008). Introduction to sukuk", Malaysian Sukuk Market Handbook (2nd Ed.). Kuala Lumpur: . RAM Rating Services Berhad.

Klein, P. O., Weill, L., \& Godlewski, C. J. (2018). How sukuk shapes firm performance. World Economy, 41(3), 699-722. https://doi.org/10.1111/twec.12509

Labuan IBFC Inc. (2018). IIFM sukuk report 2018: A comprehensive study of the global sukuk market. Kuala Lumpur. Retrieved from http://www.iifm.net/about_iifm/iifm-annual-sukuk

Liquidity Management Centre website. (2008). Sukuk securitisation concept. Retrieved from http://www.lmcbahrain.com/

Mohamad, N. E. A., \& Mohd Saad, N. (2012). Sukuk in Malaysian Capital Market. In In 3 rd International Conference on Business and Economic Research (3rd ICBER 2012) proceeding (pp. 12-13).

Mohammed, W. (2015). Islamic banking and economic infrastructure developmentKenya's prospect (No. 05/15).

Mohd Zin, M. Z., Sakat, A. A., Ahmad, N. A., Mohd Nor, M. R., Bhari, A., Ishak, S., \& Jamain, M. S. (2011). The effectiveness of sukuk in Islamic finance market. Australian Journal of Basic and Applied Sciences, 5(12), 472-478.

Nafiu, O., Echchabi, A., \& Alfarisi, M. F. (2012). Sukuk As an Alternative Avenue for Infrastructure Development and Job Creation. Journal of Islamic Banking \& Finance, 29(2).

Nganga, P. S. (2016). Market Attractiveness, Industries Environment Competitiveness, Entry Mode Choice Analysis-Methods Applied AHP, SWOT, Malmquist Index, Stepwise-Regression, and Proxy Framework Methods (SSA 
region) - (Doctoral dissertation). Nagasaki University's Academic Output SITE. Retrieved from http://hdl.handle.net/10069/36562

Nmadu, Y. B., \& Mika'ilu, A. (2018). Financial Inclusion and Deepening in Nigeria: the Contribution of Jaiz Bank. Share: Jurnal Ekonomi Dan Keuangan Islam, 7(2), 95-115. https://doi.org/10.22373/share.v7i2.2300

Odunsi. W. (2017). Sukuk bond: Full list of 25 roads N1oobn proceeds will be spent on. Retrieved from http://dailypost.ng/2017/10/o9/sukuk-bond-full-list-25roads-n1oobn-proceeds-will-spent/

Ogunbado, A. F., Islam, U., Sharif, S., \& Ahmed, U. (2017). Islamic Banking and Finance in Nigeria: Exploration of its Opportunities and. International Journal of Innovative Knowledge Concepts, 5(7), 12.

Oladunjoye, M. O. (2014). Sukuk as a Tool for Infrastructural Development in Nigeria. Journal of Islamic Banking and Finance, 2(1), 335-344.

Onihaa, P. (2017). The Case for Nigerian sukuk. https://doi.org/https://www.thisdaylive.com/index.php/2017/o9/18/thecase-for-nigerian-sukuk/

Opejobi. S. (2017). N1oobn Sukuk loan: 'Christianise Nigeria with interest-free banks' - Falana mocks CAN.

Osmanovica, N., Kb, P., \& Stojanovic, I. (2020). Impacts of Islamic Banking System on Economic Growth of UAE. Journal of Talent Development and Excellence, 12(3s), 1555-1566.

Rafay, A., Sadiq, R., \& Ajmal, M. (2017). Uniform framework for Sukuk al-Ijarah - a proposed model for all madhahib. Journal of Islamic Accounting and Business Research, 8(4), 420-454. https://doi.org/10.1108/JIABR-09-2015-0042

Rahman, A. S., Hilmy, H. M. A., \& Saifurrahman, A. (2018). Gap Analysis between BNM Regulation and Application of Musharakah Mutanaqisah in Islamic Banking. Journal of Islamic Finance, $7(1), \quad 38-50$. https://doi.org/10.12816/0051134

Rehman, A. A. (2020). Islamic finance takes on COVID-19. Retrieved from https://www.undp.org/content/undp/en/home/blog/2020/islamic-financetakes-on-covid-19.html

Rita. 1. (2013). Nigeria introduces new Islamic finance regulations. Retrieved from https://www.worldfinance.com/banking/islamic-banking/nigeria-introducesnew-islamic-finance-regulations

Saeed, A. (1995). The moral context of the prohibition of Riba in Islam revisited. American Journal of Islamic Social Sciences, 12(4), 496-517.

SCM. (2009, January). Securities Commission Malaysia. The Islamic Securities (Sukuk) Market. Securitization. Islamic Finance News Guide. January edition, pp. 33-36.

Shariff, R. A. M., \& Rahman, A. R. A. (2003). An exploratory study of Ijarah accounting practices in Malaysian Financial Institutions. International Journal of Islamic Financial Services, 5(3), 1-15.

Sherif, M., \& Hussnain, S. (2017). Family Takaful in developing countries: the case of Middle East and North Africa (MENA). International Journal of Islamic and 
Middle Eastern Finance and Management, 1O(3), 371-399. https://doi.org/10.1108/IMEFM-01-2016-0016

SULAIMAN. A.K. (2012). Sukuk Issuance in Saudi Arabia: Recent Trends and Positive Expectations. Durham University, Durham, United Kingdom.

Sulaiman K. O. (2020). Customer's expectations in Sukuk (Islamic bond) and the question of Islamization of Nigerian. The Islamic College University Journal, $55,23-45$.

Tahmoures, A. A. (2013). Compare and Contrast Sukuk ( Islamic Bonds ) with Conventional Bonds, Are they Compatible? Journal of Global Business Management, 9(1), 44-52.

Thani, N. (2012). An Introduction to Islamic and Conventional Corporate Finance. Thomson Reuters Malaysia. Thomson Reuters Malaysia.

Uddin, M. A., Sultan, Y., Hosen, M., \& Ullah, N. (2015). A Critical Analysis of Islamic Bond: A Case study on Sunway Treasury Sukuk. Munich Personal RePEc Archive, Paper No.(47061). Retrieved from https://ideas.repec.org/p/pra/mprapa/68785.html

Vanguard. (2017). FG commences pre-offer road show for N1oobn Sukuk. Retrieved from https://www.vanguardngr.com/2017/o9/fg-commences-pre-offer-roadshow-n1oobn-sukuk/

Vishwanath, S. R., \& Azmi, S. (2009). An overview of Islamic sukuk bonds. The Journal of Project Finance, 14(4), 58.

Yaakub, N. I., Shah, H., Mujani, W. K., Jusoff, K., \& Hamid, M. A. (2011). Asset ownership and investor's protection under Sukuk Ijarah. Middle-East Journal of Scientific Research, 7(7), 22-30.

Yahaya, O. A., \& Lamidi, Y. (2015). Empirical examination of the financial performance of islamic banking in Nigeria: a case study approach. International Journal of Accounting Research, 2(7), 1-13.

Yahya, M., Hussin, M., \& Muhammad, F. (2012). Development of Sukuk Ijarah in Malaysia. Journal of Islamic Economics, Banking and Finance, 8(2), 92-101.

Yunusa, M., \& Nordin, N. B. (2015). Religious Challenges of Islamic Banking in Nigeria. International Journal of Academic Research in Business and Social Sciences, 5(4), 78-98. https://doi.org/10.6007/ijarbss/v5-i4/1543

Zolfaghari P. (2017). An Introduction to Islamic Securities (Sukuk), 2, 1-42. https://doi.org/10.1109/68.841264 